\title{
The International Commission of
}

\author{
Jurists
}


University of Pennsylvania Press

Pennsylvania Studies in Human Rights

Edited by Bert B. Lockwood, Jr.

A complete listing of the books in this series appears at the back of this volume. 


\section{The International Commission of}

Jurists

Global Advocates for Human Rights

Howard B. Tolley, Jr.

University of Pennsylvania Press

Philadelphia 
Copyright (C) 1994 by the University of Pennsylvania Press

All rights reserved

Printed in the United States of America

Library of Congress Cataloging-in-Publication Data

Tolley, Howard.

The International Commission of Jurists: global advocates for human rights / Howard B. Tolley, Jr.

p. $\mathrm{cm}$.--(Pennsylvania studies in human rights)

Includes bibliographical references and index.

ISBN 0-8122-3254-2

1. International Commission of Jurists (1952- ) 2. Rule of law. 3. Human rights. I. Title. II. Series.

KI10.I46T65 1994

$341.4^{\prime} 81-\mathrm{dc} 20$ 
This work is dedicated to the spirit of my son, Naren Justin Tolley, who died ten days after his seventeenth birthday on January 29, 1991. A poem Naren wrote appears below as a father's

\section{T R I B U T E}

This poem is for you

In this feeling of excitement which never dies

This is for the power you have to bring people alive

With your strong reassuring hands

Lifting us to the summit of emotions

Your powerful voice willing us to endeavor past our dreams

A search for inner fulfillment your powerful form

Rising from the churches, synagogues, temples and forest

Leaping like a panther

Strong and able to race into any soul in the farthest recess of the mind

Always helping

Always strong

Never a dim spirit dispelling doubt

This poem is for you-will of man. 
This page intentionally left blank 